DOI: https://doi.org/10.32839/2304-5809/2019-9-73-2

UDC 519.6:001.5

\title{
SOLUTION OF THE APPLIED OPTIMIZATION PROBLEMS
}

Summary. The research of the author is devoted to the issues of optimization of the parameters of multilayer systems containing local, discrete sources of thermal loads. The paper proposed one of the possible approaches to the implementation of optimization of the parameters of such systems. Due to the fact that in practice it is often necessary to deal with multilayered materials of complex spatial form, which, for example, have zones of prohibition on the movement of division routes, the author pays considerable attention to the determination and verification of the validity of the calculated and applied optimization mathematical models conditions for improving the quality of the biotechnological process. Despite the focus of this work to the optimization of multilayer biosystems, the uniqueness of the author's research consists in their broad applicability for optimizing a number of multilayer systems.

Keywords: mathematical modeling, optimization, correctness, boundary value problems, pseudodifferential operators.

Левкін Д.А.

Харківський національний технічний університет сільського господарства імені Петра Василенка

\section{РОЗВ’ЯЗАННЯ ПРИКЛАДНИХ ЗАДАЧ ОПТИМІЗАЦІї}

Анотація. В роботі наведений процес математичного моделювання та оптимізації багатошарових біотехнологічних систем, які містять локальні, дискретні джерела дії. Особливу увагу автор приділив кулеподібним багатошаровим мікробіологічним матеріалам під дією сканованих джерел лазерного випромінювання. Зазначимо, що особливості об’єкта дослідження та специфіка електромагнітної дії призводить до неможливості застосування для доказу умов коректності традиційної теорії існування та единості розв’язку крайових задач, що описують його стан. Труднощі з доказами умов коректності належать цілому класу багатошарових об'ектів складної просторової форми, які мають, наприклад, зони заборони на проходження трас лазерного ділення. Для подолання зазначених складнощів, автор пропонуе застосувати теорію псевдодиференціальних операторів над простором узагальнених функцій. Це дає можливість, не конкретизуючи об'єкт дослідження (багатошаровий мікробіологічний матеріал під дією лазерного променя), гарантувати коректність крайових задач, що, в свою чергу, дозволить гарантувати адекватність розрахункових та прикладних оптимізаційних математичних моделей. Досліджені та враховані автором характерні особливості математичної моделі основної оптимізаційної задачі та прикладних математичних моделей, дозволять ефективно обрати методи для чисельної та програмно-апаратної реалізації. Для здійснення оптимізації в роботі представлений підхід для реалізації одразу двох прикладних оптимізаційних математичних моделей та наведена обчислювальна структура, що складаеться з широко відомих чисельних методів. Відзначимо, що незважаючи на спрямованість досліджень автора на розрахунок та оптимізацію біотехнологічних систем, результати дослідження мають універсальний характер і їх можна застосовувати для оптимізації механічних, електротехнічних та інших систем, що містять локальні, дискретні джерела відповідних фрізичних полів. Однак, при цьому зазнають зміни постановки крайових задач та чисельні методи реалізації прикладних оптимізаційних математичних моделей.

Ключові слова:математичне моделювання, оптимізація, коректність, крайові задачі, псевдодиференщіальні оператори.

Tormulation of the problem. Today, one To the main ways to search for the optimal values of the parameters of multilayer and single-layer systems containing local mobile sources of physical fields remains the experiment. Obtaining experimentally data is associated with excessive costs of technical resources of sources of loading and the expensive material consumption. To overcome the difficulties, it is necessary to develop the theory of such systems calculation and optimization of. It is worth noting that the study of many authors is aimed at optimizing specific systems under the influence of concentrated sources of the corresponding physical fields [1-4]. Despite the significant achievements of the authors in solving the problems of calculating, managing, and optimizing the parameters of single-layer and multilayer systems, relatively little work has been devoted to the optimization of the whole class of systems. Thus, to overcome the difficulties of systematization and formalization of applied optimization for mathematical models for multilayer systems, the averaging of geometrical parameters, chemical composition, and thermophysical characteristics of the objects of the research is often carried out. This leads to averaging of the obtained values of the objective function, rough estimates of changes in the parameters of the systems, and as a result of this, errors in the processes of calculating the objective function and optimizing its parameters.

According to the author, along with an increase in the number of formalized applied optimization mathematical models, the definition and verification of the fulfillment of the conditions for the correctness of computational and applied optimization mathematical models is also required [5]. The construction and implementation of a larger number of applied optimization mathematical models that 
take into account the structural features of multilayer microbiological material exposed will improve the accuracy and speed of optimization, and, as a result, improve the quality of biotechnological processes.

The object of the author's research is a multi-layer spherical microbiological material containing sources of thermal loading. The uniqueness of the author's research consists in the formalization at once of two applied optimization mathematical models of the process of thermal exposure, taking into account the structure of microbiological material and the characteristics of thermal exposure. At the same time, the studies conducted in this work are of a generalized nature and the author does not focus on a specific object of study. This means that, in dealing with a specific object of study, it is possible to carry out the calculation and optimization of various systems subjected to thermal loads.

Analysis of recent research and publications. We will analyze the scientific publications related to the optimization questions and the assignment of control parameters of systems containing local mobile sources of physical fields [1; 4]. In [1], the issues of calculation and optimization of thermal, mechanical, electrical and other systems under the influence of sources of physical fields were considered. In [2], the author carried out the calculation and specification of the technical parameters of technological systems under laser irradiation. However, in papers $[1 ; 2]$, the issues of calculating and optimizing biotechnological systems were not considered under laser exposure. Important in them is the common approach used to calculate and optimize systems with distributed parameters, which include multi-layer microbiological material under laser irradiation. At the same time, its state is significantly different in the formulation and implementation of the initial boundary value problems, and the process of optimizing the parameters of temperature fields has its own characteristics $[6 ; 7]$.

Despite the fact that the authors of [3] showed the temperature of the laser heating of the embryo and at the same time took into account its 3 - layer structure, these temperatures were found for several specific modes of laser exposure to the embryo, the biochemical composition of the embryo layers was not taken into account not given the process of optimizing the control parameters of the temperature field. In addition, in order to increase cell viability and reduce uncontrolled costs of technical resources, according to the author, it is advisable to optimize a larger number of parameters. This will undoubtedly entail an increase in the number of applied and applied optimization mathematical models, and therefore will increase the time and volume of machine memory required for this.

The purpose of the article. To optimize the parameters of electron beam exposure to multilayer microbiological material to reduce the cost of technical resources and improve survival. In the framework of solving this basic problem, the author proposed one of the possible approaches to the implementation of the calculation and optimization of the control parameters of multilayer microbiological systems. The universality of the research and the generalization of the approach allows us to de- clare a wide range of their applicability for solving the whole class of problems related to the optimization of systems under the influence of the corresponding physical fields sources.

The presentation of the main material. The basis of the computational mathematical model of the process of electron-beam action on a multilayer spherical microbiological material lies in the boundary problem of a system of non-stationary, multidimensional differential heat conduction equations in partial derivatives:

$$
\begin{aligned}
& \left(\rho_{1} c_{1} \frac{\partial T_{1}}{\partial t}-\lambda_{1}\left(\frac{\partial^{2} T_{1}}{\partial r^{2}}+\frac{2}{r} \frac{\partial T_{1}}{\partial r}\right)+q_{1}=0, \quad r \in\left[0 ; r_{1}\right], t \in\left[0 ; t_{1}\right] ;\right. \\
& \left\{\rho_{2} c_{2} \frac{\partial T_{2}}{\partial t}-\lambda_{2}\left(\frac{\partial^{2} T_{2}}{\partial r^{2}}+\frac{2}{r} \frac{\partial T_{2}}{\partial r}\right)+q_{2}=0, \quad r \in\left[r_{1} ; r_{2}\right], t \in\left[t_{1} ; t_{2}\right] ;\right. \\
& \begin{array}{llllllllllllll}
\ldots & \ldots & \ldots & \ldots & \ldots & \ldots & \ldots & \ldots & \ldots & \ldots & \ldots & \ldots & \ldots & \ldots
\end{array} \\
& \rho_{N} c_{N} \frac{\partial T_{N}}{\partial t}-\lambda_{N}\left(\frac{\partial^{2} T_{N}}{\partial r^{2}}+\frac{2}{r} \frac{\partial T_{N}}{\partial r}\right)+q_{N}=0, \quad r \in\left[r_{N-1} ; r_{N}\right], t \in\left[t_{N-1} ; t_{N}\right],
\end{aligned}
$$

where $\rho_{e}$ - the density coefficient of the $e$-th layer of a multilayer ( $N$-layer) microbiological material, where $e=1, . ., N$;

$c_{e}$ - coefficient of heat capacity;

$T_{e}=T_{e}(r, t)$ - temperature field at the points of the $e$-th layer of microbiological material;

$r_{e}-$ the distance from the center of the source of heat exposure to the point in the $e$-th layer of multilayer microbiological material, in which the value of the temperature field is calculated;

$t_{e}$ - duration of heat exposure:

$\lambda_{e}-$ coefficient of thermal conductivity;

$q_{e}-$ specific power density of thermal loads in the microbiological material.

Dirichlet boundary conditions set the beginning and end of laser exposure:

$$
\left\{\begin{array}{l}
T\left(r_{0}, t_{0}\right)=T_{0} ; \\
T\left(r_{N}, t_{N}\right)=T_{h},
\end{array}\right.
$$

where $h$ is the duration of exposure.

Taking into account the multi-layer structure of microbiological material, the equality of media section is introduced:

$$
\begin{aligned}
& \int T_{1}\left(r_{1}, t_{1}\right)=T_{2}\left(r_{2}, t_{2}\right), \quad-\lambda_{1} \frac{\partial T_{1}}{\partial r}=-\lambda_{2} \frac{\partial T_{2}}{\partial r}, \quad r \in\left[r_{1} ; r_{2}\right] ; \\
& \left\{T_{2}\left(r_{2}, t_{2}\right)=T_{3}\left(r_{3}, t_{3}\right), \quad-\lambda_{2} \frac{\partial T_{2}}{\partial r}=-\lambda_{3} \frac{\partial T_{3}}{\partial r}, \quad r \in\left[r_{2} ; r_{3}\right] ;\right. \\
& \begin{array}{llllllll}
\ldots & \ldots & \ldots & \ldots & \ldots & \ldots &
\end{array} \\
& T_{N-1}\left(r_{N-1}, t_{N-1}\right)=T_{N}\left(r_{N}, t_{N}\right), \quad-\lambda_{N-1} \frac{\partial T_{N-1}}{\partial r}=-\lambda_{N} \frac{\partial T_{N}}{\partial r}, \quad r \in\left[r_{N-1} ; r_{N}\right] .
\end{aligned}
$$

The conditions of heat exchange on the border of the outer shell of microbio-logical material and its environment:

$$
-\lambda_{1} \frac{\partial T_{1}}{\partial r}(0, t)=\sigma S,
$$

where $t$ - the duration of exposure;

$\sigma-$ specific heat flux;

$S$ - area of impact source.

Using the example of an embryo under the influence of a laser beam, the author [8] showed the numerical implementation of this computational mathematical model and found the temperature of laser heating of the layers of a microbiological object. We present a mathematical model of the main optimi- 
"Молодий вчений" • № 9 (73) • вересень, 2019 р.

zation problem of improving the quality of thermal effects on multilayer microbiological material.

The mathematical model of the main optimization problem is that it is necessary to find such parameters of the vector of heat $z^{*}=(x, y, z, t, u, E, s(t), v(t), Q(x, y, z, t), S): x, y, z-\operatorname{size}$ of the multilayer microbiological material area; $t-$ duration of exposure; $u$ - source intensity; $\mathrm{E}-$ the energy of the laser beam; $s(t)$ - source path; $v(t)-$ source speed; $Q(x, y, z, t)$ - heat exposure density; $S$ - the area of the laser source, which would ensure the achievement of the extremum of the objective $T=T\left(x, y, z, t, z^{*}\right)$ at the given system of restrictions on the values of the temperature field and on the parameters of the vector of heat exposure. Based on the formulation of the main optimization problem, in order to optimize the parameters of the temperature field in [6; 7], the author proposed and systematized applied optimization mathematical models. At the same time, to find the optimal values of the parameters of the objective function, it is advisable to use not one, but several application-oriented optimization mathematical models. Their novelty consists in the fact that, in the implementation of parameterization, the temperature fields of microbiological materials are presented depending on the characteristics of a discrete moving source of exposure.

We show one of the possible approaches for the implementation of optimization. Let us reduce the dimension of the parameters of the target function and select some arbitrary parameters as optimized ones. We construct a large uniform grid of their discretization. We solve the boundary problem of the system of differential equations of heat conduction. To assess the traumability of microbiological material with the values of optimized parameters at the nodal points of a large uniform grid, it is possible to apply the following relationship:

$$
K=\frac{V_{\text {segm. }}}{V} \times 100 \%
$$

where $V_{\text {segm. }}$ - the volume of the irradiated segment of the multilayer microbiological material;

$V$ - volume of microbiological material.

By the step method, we will move along the nodes of the coarse grid from the node, in which a greater value of the traumability of the microbiological material to the node with a lower value of the traumability is achieved. To find points with optimal values of the selected parameters, we use the method of directional extremum search of the temperature field, comparing the injuries at the nodal points of a large uniform grid and choosing a node with a lower value of injuries.

In the vicinity of nodes with lower injuries, we will grind the grid model step and the process of analyzing and finding local extrema will be repeated until, for example, the specified accuracy of solving boundary value problems, the specified error value of the microbiological material traumability value is reached, the expiration time allowed for optimization.

Conclusions and offers. One of the possible approaches to the calculation and optimization of multilayer systems containing local, discrete sources of thermal loads is shown. The universality of the author's research will allow the proposed approach to be applied to the calculation and optimization of temperature fields of various microbiological objects that are subject to thermal loading. This will make it possible to increase the efficiency (increase in speed, accuracy and decrease in computer memory) of solving boundary value problems and optimizing multilayer systems, as well as to offer ways and means for software and hardware implementation of applied optimization mathematical models in order to improve the quality of impact processes. At the same time, according to the author, to improve the accuracy and speed of implementation of applied optimization mathematical models it is required: formalization of a larger number of applied optimization mathematical models taking into account the unevenness of the outer layer of microbiological material, its multi-layer, inhomogeneous structure and features of the electromagnetic effect; the presence of comparative estimates of the number of local extrema of the goal function of solving boundary value problems from numerical methods for their solution; an increase in the accuracy of comparative relations for estimating the time expenditures of PC software and hardware for the implementation of mathematical models.

\section{References:}

1. Stoyan, Yu.G., \& Putyatin, V.P. (1981). Razmeschenie istochnikov fizicheskih poley [Location of physical field sources]. Kyiv: Nauk. dumka. (in Russian)

2. Chubarov, E.P. (1985). Upravlenie sistemami s podvizhnymi istochnikami vozdeistviia [Management of systems with moving sources of impact]. Moskva : Energoatomizdat. (in Russian)

3. Douglas-Hamilton, D.H., \& Conia, J. (2001). Thermal effects in laser-assisted pre-embryo zona drilling. Journal of Biomedical Optics, vol. 6, Issue 2, p. 205. doi: 10.1117/1.1353796

4. Rink, K., Delacretaz, G., \& Salathe, R. (1996). Non-contact microdrilling of mouse zona pellucida with an objectivedelivered 1.48 um diode laser. Lasers in Surgery and Medicine, vol. 18, pp. 52-62.

5. Makarov, A.A., \& Levkin, D.A. (2014). Mnogotochechnaia kraevaia zadacha dlia psevdodifferentsialnykh uravnenii v polisloe [Multipoint boundary value problem for pseudodifferential equations in a multilayer]. Visnyk Kharkivskoho natsionalnoho universytetu imeni V.N. Karazina. Seriia: Matematyka, prykladna matematyka $i$ mekhanika, vol. 69, no. 1120, pp. 64-74. (in Russian)

6. Megel', Yu.E., Putyatin, V.P.,Levkin, D.A., \& Levkin,A.V.(2017). Matematycheskoe modelyrovanyei optymyzatsyia parametrov deistvyia lazernoho lucha na mnogosloynyie biomaterialyi [Mathematical modeling and optimization of the parameters of the action of the laser beam on multilayer biomaterials]. Visnyk Natsionalnoho tekhnichnoho universytetu "KhPI". Zbirnyk naukovykh prats. Seriia: Mekhaniko-tekhnolohichni systemy ta kompleksy. Kharkiv: NTU «KhPI», vol. 20, no. 1242, pp. 60-64. (in Russian)

7. Levkin, D.A. (2014). Matematychni modeli optymizatsii parametriv dii lazernoho promenia na bahatosharovi biosystemy [Mathematical models of optimization of laser beam parameters on multilayered biosystems]. Visnyk Natsionalnoho tekhnichnoho universytetu "KhPI". Zbirnyk naukovykh prats. Seriia: Mekhaniko-tekhnolohichni systemy ta kompleksy. Kharkiv: NTU «KhPI», vol. 60, no. 1102, pp. 77-84. (in Ukrainian) 
8. Levkin D.A. (2019). Matematycheskoe modelyrovanye i optymyzatsyia mnogosloinykh sistem [Mathematical modeling and optimization of multilayer systems]. Enerhetyka $i$ avtomatyka. Kyiv: NUBiP Ukrainy, 1(41), pp. 45-56. doi: 10.31548/energiya2019.01.045 (in Russian)

\section{Список літератури:}

1. Стоян Ю.Г., Путятин В.П. Размещение источников физических полей. Київ : Наукова думка, 1981. С. $59-87$.

2. Чубаров Е.П. Управление системами с подвижными источниками воздействия. Москва : Энергоатомиздат, 1985. 288 c.

3. Douglas-Hamilton D.H., Conia J. Thermal effects in laser-assisted pre-embryo zona drilling. Journal of Biomedical Optics. 2001. Vol. 6, Issue 2. 205 p. doi: 10.1117/1.1353796

4. Rink K., Delacretaz G., Salathe R. Non-contact microdrilling of mouse zona pellucida with an objective-delivered 1.48 um diode laser. Lasers in Surgery and Medicine. 1996. Vol. 18. Pp. 52-62.

5. Макаров А.А., Левкин Д.А. Многоточечная краевая задача для псевдодифференциальных уравнений в полислое. Вісник Харківського національного університету ілені В.Н. Каразіна. Серія "Мателатика, прикладна мателатика і механіка». Харків, 2014. Вип. 69. № 1120. С. 64-74.

6. Мегель Ю.Е., Путятин В.П., Левкин Д.А., Левкин А.В. Математическое моделирование и оптимизация параметров действия лазерного луча на многослойные биоматериалы. Вісник Національного технічного університету "ХПІ". Збірник наукових праць. Серія "Механіко-технологічні системи та комплекси". Харків : НТУ «ХПІ», 2017. № 20 (1242). С. 60-64.

7. Левкін Д.А. Математичні моделі оптимізації параметрів дії лазерного променя на багатошарові біосистеми. Вісник Національного технічного університету "ХПІ". Збірник наукових праць. Серія "Механікотехнологічні систели та колплекси». Харків : НТУ «ХПІ», 2014. № 60 (1102). С. 77-84.

8. Левкин Д.А. Математическое моделирование и оптимизация многослойных систем. Енергетика $i$ автолатика. Київ : НУБіП України, 2019. № 1(41). С. 45-56. doi: 10.31548/energiya2019.01.045 